Article

\title{
Mobile Apps Use and WOM in the Food Delivery Sector: The Role of Planned Behavior, Perceived Security and Customer Lifestyle Compatibility
}

\author{
Daniel Belanche ${ }^{1, *(\mathbb{D})}$, Marta Flavián ${ }^{1}\left(\mathbb{D}\right.$ and Alfredo Pérez-Rueda ${ }^{2}$ (D) \\ 1 Faculty of Economy and Business, University of Zaragoza, 50005 Zaragoza, Spain; mflavian@unizar.es \\ 2 Faculty of Social and Human Sciences, University of Zaragoza, 44003 Teruel, Spain; aperu@unizar.es \\ * Correspondence: belan@unizar.es
}

Received: 30 April 2020; Accepted: 21 May 2020; Published: 22 May 2020

check for updates

\begin{abstract}
This research examines the phenomenon of food delivery services from the mobile app user's perspective and how consumers' lifestyles are changing because of the convenience provided by the apps. By means of an online survey targeted at US food delivery app customers, our study analyzes the main motivations that lead them to use and recommend these technology-based services. The results of the study revealed that some of the theory of planned behavior model variables (i.e., attitude toward the behavior, subjective norms), influence customer use and word-of-mouth (WOM) intentions. Security influences intention to spread WOM, whereas customer lifestyle compatibility influences intention to use the food delivery apps. A post hoc analysis revealed that perceived control is only important for older customers, who need to perceive that they control the apps before they will recommend them to other customers. The findings of the study are discussed and contrasted with previous research in the field. The managerial implications derived from the findings provide practical guidance for food delivery app companies. Further research avenues are suggested to encourage scholars to continue investigating the challenge of the diffusion of mobile apps in the food delivery and related sectors.
\end{abstract}

Keywords: food delivery; mobile apps; security; lifestyle; WOM; consumer behavior; digital markets; home delivery; smartphones

\section{Introduction}

Today's accelerated lifestyle and the intense use of technologies encourage customers to purchase through mobile apps [1,2]. People search for new alternatives to make everyday tasks easier and adapted to their lifestyles [3,4]. In particular, last-mile logistic services are increasingly offering innovative solutions ranging from home deliveries to logistic service providers placing e-commerce packages in self-collection points [5]. Home delivery services are convenient for online shoppers [6] and are an essential part of urban logistics services [7]. Furthermore, thanks to mobile phone applications, home delivery services have become even more important because customers prefer to enjoy products at the right time, right place, in the right quantity, and in the right condition $[6,8]$.

The delivery service phenomenon has been defined as "the delivery service offered by a store to deliver its products to the buyer's home" [9]. Among online delivery services, food delivery is one of the fastest growing [10]. Although the concept is not new, several companies have emerged in recent years and gained worldwide popularity because of increased mobile app penetration [11]. Home delivery provides value-added to all the actors in the system, which, while it adds complexity to the distribution process, creates competitive advantage by better satisfying customers [12,13].

In the food delivery subsector home delivery is the activity in which a food distribution service company acts as an intermediary between restaurants or bars and customers [14]. The business 
model of food delivery companies is based on the advantages offered by the Internet, that is, on the technological capability to connect different distribution process agents. Today, this business is worth some USD 94,385,000,000 globally [15]. Food delivery companies are taking control of the food business market because they offer an easy and fast service oriented to better fulfill customers' demands for convenience [16]. Indeed, revenues are expected to achieve an annual growth rate of $9.3 \%$, reaching a market volume of USD 134,490,000,000 by 2023 [15]. Previous studies in the distribution field have confirmed that the use of apps is crucial for gaining a competitive advantage in the sector [11].

Mobile apps are today an essential part of everyday life [17]. High-speed Internet access, the increased proliferation of smartphones [2], advances in personalized and interactive apps (e.g., geo-tracking [18]), and the fast rhythm of modern life [19] have created a fertile environment for the adoption of mobile applications. Indeed, the 2.7 billion smartphone users across the world spend $90 \%$ of the time they spend on their mobiles on apps [20]. The average smartphone owner uses 30 apps per month and nine apps per day; this development has changed individuals' lifestyles and turned occasional app use into a daily habit [21]. Focusing on food delivery, a third of US customers of these services spend more than USD 50 per order [22], and food orders placed via mobile apps will be a USD $38,000,000,000$ industry by the end of 2020 [23]. The mobile food delivery app market in the US is led by Seamless, followed by GrubHub (with 20 million active users and 115,000 associated restaurants) and Uber Eats [24]. In Europe, the market is led by apps that operate in several countries, such as the Denmark-based Just-Eat (24 million active global customers and 93,700 restaurants), the British Deliveroo, and the Spanish Glovo [25]. By using food delivery apps, customers can access food from where they want and order their favorites from a wide range of restaurants at convenient times and locations [11]. Although food delivery apps are an important delivery context, little is known about why people use and recommend them. Therefore, it is crucial for practitioners and academics to better understand customers' perceptions and motivations to use food delivery apps and to spread word-of-mouth (WOM) about them among other customers [26].

The technology, especially the mobile app, plays a central role in the food delivery process. In particular, in last-mile logistic services, online technologies allow companies to deliver orders to a specific place at a specific moment with high accuracy and reliability [27]. The food delivery service commonly has a fixed cost, which is based on agreements made with the establishments and on the distance between the restaurant and the consumer's address. This simple process led to a diffusion of these food delivery mobile apps among customers and fierce competition between platforms. In this sense, the previous literature identified some key factors in mobile app use and recommendation, such as attitude toward the app [28,29]. On the other hand, previous studies returned contradictory results about the influence of other factors, such as consumers' perceived control [30-32], an aspect that can be strategic in the food delivery context [33]. Furthermore, other social factors could be important in the context of mobile app usage, such as lifestyle compatibility, which has not yet been examined in the literature in this field. It will, thus, be very important for the food service companies to assess the principal factors that motivate the customer to use, and diffuse WOM about, their apps before they add further innovative features/updates; this will allow them to better adapt to consumers' needs and demands (e.g., drones reduce energy consumption and carbon dioxide emissions [34].)

Over the last three decades marketing research has focused strongly on new technology evaluation and adoption [35-39]. Social-psychological models are useful tools in this regard for analyzing decision-making factors and processes; the theory of planned behavior (TPB) [35] is a model commonly used to predict consumer intentions and behaviors in this domain [36]. The TPB proposes that the individual's attitudes, subjective perceptions about others' opinions, and self-perceptions about available resources (e.g., skills) determine his/her behavioral intentions and behaviors [40]. However, some authors found that in specific digital contexts customers are motivated by particular technological and sociological factors, such as perceptions of security [41] and customer lifestyle [36]. Security breaches associated with online commercial transactions are a major impediment to the more rapid development of online delivery apps [42]. For example, in September 2019, 172 available Android 
apps contained some form of malware, and these apps had been installed more than 335 million times [43]. Prior studies noted that Internet transactions require customers to place their trust in the firm's security, since they have to provide personal information and credit card numbers [44,45]. From a complimentary sociological approach, the previous literature identified lifestyle as a main determinant of the individual's intention to adopt products, brands, and services [36,46]. Lifestyle is a well-known research variable for segmenting target markets [47]. Therefore, we aim to better understand the relative importance of security perceptions and consumer lifestyles, in order to design appropriate solutions, thereby attracting new and retaining current users.

To advance the previous knowledge in the field we aim to confirm whether the traditional variables proposed in the technology adoption literature continue to be relevant in this novel context, and to what extent specific technological and sociological factors directly related to food delivery mobile apps (i.e., security and lifestyle compatibility) play an important role in customer decision-making. In addition, whereas previous research into food delivery app adoption focused on intention to use, our research goes one step further by proposing that both consumer use and WOM (word-of-mouth) intentions are crucial for the success of these technology-based services. This contribution is particularly valuable, given the growing importance of consumer WOM as a source of information that impacts on other customers' opinions and decisions [48,49]. Consequently, based on the TPB [35] and previous research into technology acceptance in the current home delivery setting, our study proposes an integrated framework to evaluate the main motivators of customers' use of, and WOM intentions for, online food delivery services.

The contribution of this research is threefold. First, the article contributes to the better understanding of the food delivery phenomenon and the nature of the basic determinants (e.g., subjective norms as a social influence) that are contributing to the growth of the food delivery industry from a customer perspective. A post hoc analysis helps clarify the role of perceived control, which seems to be partly dependent on the customer's age. Second, as the business model relies on technology (i.e., smartphone applications, online orders), we explore whether perceived security, previously examined in other contexts (e.g., e-commerce), is relevant in the case of food delivery apps. Third, we explore whether a sociological aspect, mobile app lifestyle compatibility-if mobile apps fit the consumer's lifestyle-has an impact on customers' intention to use, and to spread WOM about, these services. Finally, we provide practitioners with a useful guide to the key factors (e.g., demographic segmentation) that must be managed to guarantee the success and sustainability of these recently introduced services.

The paper is structured as follows. An initial section explains the food delivery service concept, how it works, and how it has evolved in recent years. The literature review section then discusses the TPB model, and the current importance of perceived security and customer lifestyle in the success of mobile apps. The research hypotheses are then formulated. Thereafter, the methodology section describes the procedure conducted to collect customers' opinions and perceptions about food delivery mobile apps and the analyses performed to test the hypotheses. The discussion section then presents the main conclusions derived from the results and their implications for management. Finally, we describe the main limitations of the study and suggest further research lines to advance this emerging field. Overall, this research clarifies which traditional and novel context-specific factors motivate customers to use and recommend food delivery mobile apps and contribute to the successful diffusion of these technology-based services.

\section{Literature Review}

\section{Theoretical Underpinnings}

The theory of planned behavior (TPB), which considers the roles of the individual and social influence, is one of the most extensively accepted in the explanation of technology adoption behaviors [38]. The TPB, developed by Ajzen [35], has been used to explain various behaviors 
such as understanding how users interact with virtual communities [50], online services [37], students' intention to use technology [51], mobile services [38], last-mile logistic services [5], and drone delivery [52].

The TPB is based on the theory of reasoned action (TRA). The TRA proposes that behavioral intentions are conditioned by attitudes and subjective, or social, norms that pressure the individual to adopt specific behaviors $[53,54]$. More recently, Ajzen added to the TRA model a third explanatory element of consumer intentions and behavior, the variable of perceived control [55,56], thus developing the TPB model. Consequently, the TPB model establishes that individual attitudes, subjective norms, and perceived control explain the behavioral intention of the individual and, thus, actual behaviors [35].

To better understand the diffusion of food delivery apps among customers, this research aims to explain the two most crucial indicators of customer loyalty in mobile app-based businesses: intention to use the food delivery app and WOM intentions, that is, the intention to recommend the app to other customers [57]. Warshaw and Davis [58] defined intention to use as "the degree to which a person has formulated conscious plans to perform or not perform some specified future behavior." In turn, WOM is direct face-to-face or online (eWOM) interpersonal communication. Consumers tend to assign greater credibility to information provided by other consumers similar to themselves than to traditional advertising; consequently, WOM recommendations play a more important role in reducing perceived risk when selecting alternatives [59]. This is especially important in service provision because the intangibility of services means that potential consumers cannot possess relevant knowledge before using them [60]. Therefore, other people's assessments are particularly important when evaluating services [61]. Thus, WOM intention is understood as informal communication between people about a brand, organization, or service, where the communicator is perceived as non-commercial [62].

To explain these two loyalty-related behavioral intentions (food delivery app use and WOM), we propose, see Figure 1, a holistic research framework in which key determinants identified in previous literature (i.e., the TPB model: attitude, the subjective norm, perceived control) are complemented by perceptions about technological (i.e., security) and sociological aspects (i.e., lifestyle).



Figure 1. Research framework. 


\section{Hypotheses Development}

\subsection{The Influence of Attitudes}

Previous literature focused widely on the concept of attitude and its influence on individuals' behavioral intentions, as proposed in the TPB model. Among other contexts, the influence of attitude was analyzed as a precursor of behavioral intentions in subjects' choices of tourist destinations [63], digital press [64], electronic public services [65], mobile commerce [66], and artificial intelligence services [67].

Attitude is defined as "the degree to which a person has a favorable or unfavorable evaluation or appraisal of the behavior" [35]. From this perspective, attitude can be considered an evaluative response to the possible development of a certain action (e.g., the purchase of a product), which could, to different extents, be a favorable or unfavorable response. Attitudes are acquired over time through learning processes. Thus, when the individual needs to make a decision, a previously formed attitude appears to guide behavior [68].

In our case, we understand attitude to be an overall evaluation that customers develop when they use mobile food delivery apps. This evaluation may be positive or negative, to a greater or lesser extent. For example, users of food delivery apps may have more or less positive attitudes, depending on their assessments of the apps. Therefore, if a consumer develops a positive attitude after (s)he has evaluated home delivery apps, his or her intention to use the apps and spread WOM about them will be positive. Accordingly, we propose our first hypotheses:

Hypotheses 1a (H1a): Attitude toward food delivery apps increases intention to use the apps.

Hypotheses 1b (H1b): Attitude toward food delivery apps increases intention to spread WOM about the apps.

\subsection{The Influence of the Subjective Norm}

The subjective norm reflects the strength of normative beliefs and the individual's motivation to comply with these beliefs [35]. Subjective norms reflect the social pressure that the individual perceives about issues; they have a significant impact on his or her behavioral intentions [53]. Subjective norms are largely based on the individual's need for approval [69].

Focusing on food delivery apps, it should be noted that their extraordinary growth over the last years $[15,70]$ cannot be explained without taking account of the remarkable explosion of knowledge (or buzz) about them among consumers [71]. Venkatesh and Davis [72] proposed that customers' perceptions of subjective norms are related to value perceptions and social approval. Based on these factors, consumers incorporate the beliefs of relevant others into their own belief structure; that is, if a peer suggests that using a food delivery app is worthwhile, an individual may also come to believe this [37]. The positive perception that society has of these new business models is likely to influence the subjective norms of customers in deciding whether or not to use, and spread WOM about, these services, and contributes to their generalized use among groups (e.g., friends, colleagues). For these reasons we propose the following hypotheses:

Hypotheses 2a: (H2a) The subjective norm increases intention to use food delivery apps.

Hypotheses 2b (H2b): The subjective norm increases intention to spread WOM about food delivery apps.

\subsection{The Influence of Perceived Control}

Perceived control reflects the individual's perception of his or her ability to adopt a particular behavior [35], that is, his/her belief that (s)he possesses the knowledge and/or resources required to 
develop a certain behavior [30]; an individual's need for high levels of perceived control is negatively related to his/her perceptions of self-efficacy [40].

Perceived control was considered by Bagozzi et al. [50] to be the ultimate cognitive determinant of behavioral intentions. In fact, the adoption of some behaviors is often associated with difficulties that are more relevant for certain population groups. Thus, if an individual feels unable to adopt a behavior, this lack of self-confidence will constitute a major barrier that will make it difficult or impossible to adopt it. Although home delivery system apps tend to very simple and provide an excellent user experience [51], customers need to feel that they are able to control them in order to decide to use and recommend them to others [37]. If an individual decides to use a food delivery app, knowing that (s)he can control the app and its delivery protocols will undoubtedly make it much more likely that (s)he will use the service and, as a result, will spread positive WOM about the experience. Therefore, we propose:

Hypotheses 3a (H3a): Perceived control of the food delivery app increases intention to use the app.

Hypotheses $3 \mathbf{b}(\mathbf{H} 3 \mathbf{b})$ : Perceived control of the food delivery app increases intention to spread WOM about the app.

\subsection{The Influence of Perceived Security}

The exponential growth of the mobile app market has been accompanied by a growth in mobile users' concerns about using them $[17,73]$. When using mobile apps consumers commonly need to give personal information, which makes them particularly vulnerable to the malicious use of the data [74]. Some $64 \%$ of smartphone users reported they had concerns that apps could make them open to digital identity theft [75].

Balapour, Nikkhah, and Sabherwal [17] defined perceived security in the mobile app context as "the perception of the app provider's appropriate actions to safeguard shared information from security breaches during and after transmission through the mobile phone." Previous studies in the field found that perceived security is a key factor influencing behavioral intentions to install mobile apps [76], to use mobile app features [77,78], and in customer satisfaction with mobile apps [74,79]. Specifically, Harris, Brookshire, and Chin [73] concluded that consumers' perceptions of security are crucial for dissipating risks associated with app use. Recently, Balapour, Nikkhah, and Sabherwal [17] found that when users perceive that a company's privacy policy is effective, they perceive it has higher security levels and tend to install and use its mobile apps. Furthermore, prior research showed that the consumer's perceptions of financial or privacy risks have a negative influence on the image of food delivery services [80].

Perceived security makes consumers trust that all the transaction processes will turn out well. Higher security is perceived to provide a guarantee that personal data (e.g., name, address, credit card number, etc.) will not be lost or stolen by third parties for illegal or unethical purposes [81]. Thus, consumers who perceive the transaction is secure are more likely to use, and to recommend, food delivery apps; this may help other customers in their decision-making [82]. Taking this into consideration, we propose that security perceptions about the mobile app will affect customers' use of, and WOM intentions toward, the service. Thus, the following hypotheses are presented:

Hypotheses 4a (H4a): Perceived security of the food delivery app increases intention to use the app.

Hypotheses $4 b(\mathbf{H} 4 b)$ : Perceived security of the food delivery app increases intention to spread WOM about the app.

\subsection{The Influence of Customers' Mobile App Lifestyle Compatibility}

A central aspect of marketing research into personal characteristics and shopping involves the predictive relationship between those characteristics and amount of time spent shopping [47]. 
In particular, the study of individuals' lifestyles provides a useful method of segmenting the target market [46]. Lifestyle is a well-known concept in market research and consumer behavior, but it is sometimes confused with subcultures, social movements, and status groups [83]. In the early eighties, Cosmas [84] identified the concept with the individual's way of life, specifically how (s)he spends his/her time and money. Bourdieu [85] suggested that lifestyle is a system of classified and classifying practices that represent the individual's identity and values. Some years later, Peter and Olson [86] defined lifestyle as "the manner in which people conduct their lives, including their activities, interests and opinions."

Accordingly, lifestyle compatibility influences individuals' behavior and consumption choices of products, brands, and services $[46,87]$. Thus, for marketing researchers, the identification of different consumer lifestyles provides great advantage in predicting consumer behavior $[36,88]$, specifically, intention to use [89]. The adoption of a new product is driven by the need to determine a social identity, which is reflected in the consumer's lifestyle [90]; for example, previous research found that lifestyle is an important predictor of mobile TV service adoption [36]. Similarly, Karahanna, Agarwal, and Angst [91] suggested that the compatibility of one's lifestyle with a technology that is related to prior experience and values has a direct influence on technology use. In this line, some consumers are accustomed to using apps (e.g., to communicate, buy, play, etc.), to the point where the apps are fully integrated into their daily lives. Based on the above, in the growing food delivery app sector we propose that consumers may have already developed lifestyle compatibility with continuous app use, which could affect their intention to use the apps. In addition, if consumers are accustomed to interact with apps, they will probably assume that food delivery apps will interest others [92], which would increase their WOM about the apps. Thus, the following two hypotheses are proposed:

Hypotheses 5a (H5a): Mobile app lifestyle compatibility increases intention to use food delivery apps.

Hypotheses 5b (H5b): Mobile app lifestyle compatibility increases intention to spread WOM about food delivery apps.

\subsection{The Influence of Intention to Use on Intention to Spread WOM}

Intention to use a product/service is motivated by the individual's belief that the amount of value received from consuming the product or service is greater than the value of not consuming it [93]. Consumers who perceive this greater value are motivated to use and recommend the product/service [57]. That is, through this positive WOM behavior, the consumer reinforces his/her own decision [94]. Consumers contribute to societal knowledge by reporting the value of a given product or service, in this case, a food delivery app. Brown et al. [95] suggested that previous satisfactory use of a product or service has a clear influence on the generation of positive WOM, which becomes a behavior that contributes to providing benefits to people around the consumer and which puts him/her in a positive light. Consequently, in the food delivery app context, the consumer's intention to use a food delivery app could increase their WOM intention. Taking all these points into consideration, our last hypothesis is:

Hypotheses 6 (H6): Intention to use the food delivery app increases intention to spread WOM about the app.

\subsection{Control Variables: Customer Demographics}

In addition, based on previous marketing research on the determinants of service use and the spreading of WOM among other customers (e.g., [81,96]), three key demographic variables (i.e., age, gender, and occupation) are included in our framework as control variables. The number of studies examining the role of age in consumer behavior has increased significantly in recent years [33,97]. Previous research suggested that age is an important factor in technology use, for example, in relation to user interfaces associated with age-friendly design, such as reduction in menu complexity, better 
resolution, and larger screen and button sizes [98]. In addition, previous research found that age affects the way in which information is processed [99], particularly in highly dynamic apps, [28]. Gender is also considered a key segmentation variable in marketing and plays an important role in shaping consumers' evaluations of products and services [100]. Gender differences have important effects on decision-making processes [101]. Recent studies confirmed that gender clearly alters preferences toward the use of platforms [97], apps [28], and technologies [102]. Finally, previous research highlighted the importance of having an occupation in understanding how individuals make use of technology in their everyday lives [33]. There are large differences in the behavioral patterns of customers using Internet-based services (e.g., frequency, time of the day) based on the key personal factor of occupation [103]. Therefore, understanding differences based on age, gender, and occupation helps marketers to design more precise segmentation and apply different marketing strategies based on different consumers' needs.

\section{Methodology}

\subsection{Data Collection}

To test our research hypotheses, we conducted a survey with US users of food delivery mobile apps. The questionnaire was designed and hosted on SurveyMonkey, through a specific link. Some 250 participants were recruited from a panel of US customers by a market research agency. The participants were invited to take part, receiving USD 1 for their collaboration. The questionnaire was described as an opinion survey on food delivery apps conducted for academic purposes. The survey was addressed to English-speaking customers who had used a food delivery app at least once in the previous year. After a brief description of how food delivery mobile apps operate and some control questions about their previous experience with these services, the participants had to answer questions about the research framework variables. Two cases were eliminated because of incomplete responses; thus, the final sample comprised 248 participants. Of these, $45.6 \%$ were women and $54.4 \%$ men; $14.5 \%$ were aged between 18 and 24 years, $29.4 \%$ between 25 and 34 years, $26.6 \%$ between 35 and 44 years, $16.5 \%$ between 45 and 54 years, $10.1 \%$ between 55 and 64 years, and $2.9 \%$ were older than 64 ; $56.9 \%$ had a full-time job, $10.5 \%$ had a part-time job, $10.9 \%$ were students, $8.1 \%$ were unemployed, $6.9 \%$ were retired, and the rest, $6.7 \%$, belonged to other categories (e.g., homemaker).

\subsection{Research Instrument and Measure Validation}

To operationalize the constructs of the research model measurement scales were adapted from the previous literature on food delivery services and technology use. Specifically, measures of attitude toward food delivery apps were adapted from Belanche et al. [104], the subjective norm scale was taken from Cheung and To [105] and Gracia et al. [106], the perceived control scale was taken from Taylor and Todd [30] and Yang [31], the security scale items were based on Kim et al. [107], the mobile app lifestyle compatibility scale was adapted from Taylor and Todd [30] and Dinsmore et al. [108], intention to use the food delivery app was measured with the scale of Yang [31] and, finally, the WOM intention scale was taken from Belanche et al. [57]. Each of these scales consisted of three items except for attitude, which was measured by four items. All the study constructs were measured by 7-point Likert scales ( 1 being "totally disagree" and 7 "totally agree"). Table 1 presents the items of each scale developed to measure the constructs, and their factor loadings and significance.

Partial least squares structural equation modeling (PLS-SEM) was used to analyze the research model and test the hypotheses. Specifically, statistical software SmartPLS 3.0 was employed. PLS modeling is particularly useful for testing research models formed by numerous variables under normality and non-normality data distribution assumptions (e.g., age, occupation) to identify the main drivers of a key construct, and when sample size is limited [109,110], as is the case with our study. 
Table 1. Measures used for the study constructs.

\begin{tabular}{|c|c|c|}
\hline & Factor Loading & t-Value \\
\hline \multicolumn{3}{|l|}{ Attitude } \\
\hline Using this food delivery app is a good idea & 0.908 & 64.505 \\
\hline Using this food delivery app is a wise idea & 0.930 & 92.042 \\
\hline I like the idea of using this food delivery app & 0.932 & 92.071 \\
\hline Using this food delivery app would be pleasant & 0.959 & 174.372 \\
\hline \multicolumn{3}{|l|}{ Subjective Norm } \\
\hline My family would think I should use this app & 0.943 & 71.072 \\
\hline My friends would think that I should use this app & 0.973 & 237.591 \\
\hline My colleagues would think that I should use this app & 0.962 & 147.535 \\
\hline \multicolumn{3}{|l|}{ Perceived Control } \\
\hline $\begin{array}{l}\text { When I use this app I feel that I have control over the } \\
\text { things I do }\end{array}$ & 0.913 & 83.707 \\
\hline The use of this app would be under my control & 0.874 & 35.495 \\
\hline When using this app I do not feel confused & 0.901 & 61.244 \\
\hline \multicolumn{3}{|l|}{ Security } \\
\hline $\begin{array}{l}\text { I think this app has mechanisms to ensure the safe } \\
\text { transmission of its users' information }\end{array}$ & 0.946 & 78.513 \\
\hline This app allows me to make payments securely & 0.935 & 86.718 \\
\hline I feel safe using the app for conducting transactions & 0.907 & 56.119 \\
\hline \multicolumn{3}{|l|}{ Mobile App lifestyle compatibility } \\
\hline Using mobile apps fits well with my lifestyle & 0.978 & 224.228 \\
\hline Using mobile apps fits into my lifestyle & 0.980 & 274.780 \\
\hline The setup of mobile apps is compatible with my lifestyle & 0.964 & 131.055 \\
\hline \multicolumn{3}{|l|}{ Intention to Use } \\
\hline I intend to use this service & 0.976 & 237.345 \\
\hline I think I will use this service & 0.976 & 238.865 \\
\hline I predict I will use this service & 0.968 & 138.579 \\
\hline \multicolumn{3}{|l|}{ WOM Intention } \\
\hline $\begin{array}{l}\text { If someone asked me about this service, I would give a } \\
\text { positive opinion }\end{array}$ & 0.965 & 127.890 \\
\hline $\begin{array}{l}\text { If I had the opportunity, I would highlight the advantages } \\
\text { of this service }\end{array}$ & 0.954 & 113.350 \\
\hline I would recommend this service & 0.980 & 308.965 \\
\hline
\end{tabular}

As an initial assessment of measurement validity we confirmed that all item loadings scored around 0.9 on their respective constructs (see Table 1), which is higher than the recommended benchmark of 0.7 [111]. As shown in Table 2, the composite reliabilities of all the constructs are higher than 0.9, proving their internal consistency. As an additional indicator of convergent validity, it was shown that the average variance extracted (AVE) values were also higher than 0.8 for all constructs (again, well above the benchmark of 0.5 [112], see Table 2). 
Table 2. Construct reliability.

\begin{tabular}{ccc}
\hline & Composite Reliability & Average Variance Extracted (AVE) \\
\hline Attitude & 0.964 & 0.870 \\
\hline Subjective Norm & 0.972 & 0.921 \\
\hline Perceived Control & 0.925 & 0.803 \\
\hline Security & 0.950 & 0.863 \\
\hline App lifestyle compatibility & 0.982 & 0.949 \\
\hline Intention to Use & 0.982 & 0.947 \\
\hline WOM Intention & 0.977 & 0.933 \\
\hline
\end{tabular}

To test for discriminant validity, we checked whether the value of the square roots of the AVEs were greater than their inter-construct correlations [112]. All construct pairs satisfied this criterion, supporting the discriminant validity of the measures. Table 3 shows the square root of the AVE values of the constructs in our framework, and the correlations among all the study measures.

Table 3. Correlations and discriminant validity.

\begin{tabular}{|c|c|c|c|c|c|c|c|c|c|c|}
\hline & 1. & 2 & 3 & 4 & 5 & 6 & 7 & 8 & 9 & 10 \\
\hline 1. Attitude & 0.933 & & & & & & & & & \\
\hline 2. Subjective Norm & 0.773 & 0.960 & & & & & & & & \\
\hline 3. Perceived Control & 0.755 & 0.624 & 0.896 & & & & & & & \\
\hline 4. Security & 0.425 & 0.385 & 0.450 & 0.929 & & & & & & \\
\hline $\begin{array}{l}\text { 5. App lifestyle } \\
\text { compatibility }\end{array}$ & 0.707 & 0.612 & 0.635 & 0.482 & 0.974 & & & & & \\
\hline 6. Intention to Use & 0.837 & 0.817 & 0.643 & 0.410 & 0.681 & 0.973 & & & & \\
\hline 7. WOM Intention & 0.835 & 0.824 & 0.665 & 0.472 & 0.645 & 0.885 & 0.966 & & & \\
\hline 8. Age & 0.004 & 0.008 & 0.049 & 0.026 & -0.018 & 0.009 & 0.075 & NA & & \\
\hline 9. Gender & 0.093 & 0.033 & 0.096 & -0.076 & 0.006 & 0.079 & 0.016 & -0.069 & NA & \\
\hline 10. Occupation & 0.021 & -0.034 & 0.036 & 0.054 & 0.076 & 0.064 & 0.002 & -0.039 & 0.102 & NA \\
\hline
\end{tabular}

Notes: NA: not available. The diagonal elements (in bold) are the square roots of the AVEs (variance shared between constructs and their measures); off-diagonal elements are the correlations among variables.

Finally, we tested for global model fit measures using PLS-SEM. Specifically, we verified that the normed fit index (NFI) was 0.89 , which is close to the recommended 0.90 [113]. The standardized root-mean-square residual (SRMR) of the research model is 0.04 , which is below 0.08 , indicating good model fit [113].

\section{Results}

To test the hypotheses and the structural model, the SmartPLS algorithm, followed by bootstrapping with 5000 subsamples, was employed [114]. The results are shown in Table 4. Regarding the hypotheses related to attitude toward the food delivery app, the results indicated that customer attitude positively influenced intention to use the mobile app ( $\beta=0.458, p<0.01)$ and WOM intention ( $\beta=0.229, p<0.01$ ), supporting H1a and H1b, respectively. The subjective norm also had a significant positive influence on both intention to use the food delivery app $(\beta=0.414, p<0.01)$ and WOM intention ( $\beta=0.219, p<0.01$ ), supporting H2a and H2b. Contrary to our predictions, customers' perceived control of the food delivery app did not significantly influence their intention to use it $(\beta=-0.052, p>0.10)$, nor did their WOM intention $(\beta=0.027, p>0.10)$; thus, H3a and H3b are not 
supported. Perceived security also did not significantly influence intention to use food delivery apps ( $\beta=0.018, p>0.10$ ), thus H4a is not supported. In turn, customers' perceptions of security increased their WOM intention $(\beta=0.095, p<0.05)$, supporting H4b. Finally, mobile app lifestyle compatibility had a positive and significant influence on intention to use ( $\beta=0.124, p<0.05)$, supporting H5a. Nevertheless, lifestyle did not significantly influence WOM intention ( $\beta=-0.040, p>0.10)$; thus, H5b is not supported. Intention to use also positively affected WOM intention $(\beta=0.496, p<0.01)$, supporting H6. In regard to the control variables, that is, age, gender and occupation, most of their effects on the dependent variables are not significant. Nevertheless, age positively influenced WOM intention ( $\beta=0.060, p<0.05)$, whereas occupation, that is, having a job, positively influenced intention to use food delivery apps $(\beta=0.058, p<0.05)$.

Table 4. Results: estimated parameters.

\begin{tabular}{ccc}
\hline & \multicolumn{2}{c}{ Dependent Variables } \\
\hline & Intention to Use & WOM Intention \\
\hline Attitude & $0.458^{* *}$ & $0.229^{* *}$ \\
\hline Subjective Norm & $0.414^{* *}$ & $0.219^{* *}$ \\
\hline Perceived Control & -0.052 n.s. & 0.027 n.s. \\
\hline Security & 0.018 n.s. & $0.095^{* *}$ \\
\hline App lifestyle compatibility & $0.124^{*}$ & -0.049 n.s. \\
\hline Age & 0.012 n.s. & $0.060^{*}$ \\
\hline Gender & 0.023 n.s. & -0.040 n.s. \\
\hline Occupation & $0.058^{*}$ & 0.023 n.s. \\
\hline Intention to Use & & $0.496^{* *}$ \\
\hline Notes: ${ }^{*} \mathrm{p}<0.05,^{* *} \mathrm{p}<0.01$, n.s. non-significant.
\end{tabular}

The research model explains the dependent variables to a great extent for both intention to use food delivery mobile apps $\left(R^{2}=0.778\right)$ and WOM intention $\left(R^{2}=0.839\right)$. These levels of explained variance can be considered high because they are above those habitually obtained in previous studies that explain behavioral intentions toward technology-based services [72]. As an additional assessment of the model's predictive capability we analyzed the Stone-Geisser's $Q^{2}[115,116]$. The Stone-Geisser's criterion evaluates the model's capacity to predict indicators of the endogenous latent variables through the blindfolding technique [117]. In our model, the $\mathrm{Q}^{2}$ indicator reached a value of 0.734 for intention to use, and 0.773 for WOM intention. Since both $\mathrm{Q}^{2}$ values are well above zero, the observed values are well reconstructed [111], indicating the suitability of our research model in terms of good predictive relevance.

\section{Post Hoc Analysis: Moderating Effect of Age on Perceived Control}

After observing the model results, we tried to identify why we did not find an effect of perceived control on intention to use (H3a) and WOM intention (H3b). This lack of influence is particularly noteworthy, since previous research into technology-based services has usually found that the variable has a significant positive influence (e.g., [30]), although it is sometimes non-significant in the field of mobile shopping behavior (e.g., [31,32]). Perhaps customers are already accustomed to using mobile apps for many purchase, communication, and entertainment activities, and they use and recommend these apps to others independent of their own ability to operate these technological tools. However, mobile apps often involve many options, interfaces, and interactive features not always very well understood or employed by their users. Indeed, some users find them too complex, and companies are continuously launching new app updates to increase users' experience and control of these technology-based services [118]. 
Ultimately, the question is whether perceived control never has a significant effect on use and WOM intentions, or if this holds only for certain situations or individuals. Consider, for example, older customers who are less confident about how to use new technologies. Age is, in fact, often considered a moderating factor in technology acceptance [119], specifically in mobile payment systems' adoption [120]. Older customers have more difficulty than the young in processing and responding to online stimuli [121], perceiving that they lack technological self-efficacy [122], and tend to be more resistant to change and to experimenting with new technologies [123]. Thus, perceived control may be particularly important for older customers, whereas younger customers might evaluate food delivery mobile apps without taking this factor into account.

Therefore, we performed an additional analysis to assess the potential moderating role of age on the relationships between perceived control and the dependent variables (i.e., intention to use, WOM intention). To test these influences, the moderating effects of age were included in the research framework. In line with previous research [124], the moderation was introduced as an interaction term between the standardized scores of the two variables (perceived control and age intervals). The results of this post hoc analysis revealed that age does not moderate the effect of perceived control on intention to use ( $\beta=-0.015, p>0.10)$; however, age did significantly moderate the effect of perceived control on WOM intention $(\beta=0.065, p<0.01)$. This significant effect indicates that perceived control positively influences WOM intention among older people. This finding suggests that older users would tend to recommend food delivery apps only when they perceive they are able to control them.

\section{Discussion}

The generalized use of the Internet and smartphone technologies has given companies the opportunity to reach a wide international customer base, which has created a highly competitive market to be the most popular app. In this context, food delivery services are today one of the fastest growing sectors and are expected to continue to grow and evolve during the next years [10]. In particular, these new technological platforms connect restaurants and customers in a quick and convenient way using mobile apps. To understand this new global business model and its implications, our study is based in the TPB model developed by Ajzen [35]. However, little is known about the key technological and sociological factors that motivate customers to use and recommend food delivery services. Table 5 summarizes the findings of the study, which are discussed hereafter.

Table 5. Summary of findings and hypotheses tests.

\begin{tabular}{cc}
\hline Relationship & Result \\
\hline Attitude $\rightarrow$ Intention to Use & H1a: Supported \\
\hline Attitude $\rightarrow$ WOM Intention & H1b: Supported \\
\hline Subjective Norm $\rightarrow$ Intention to Use & H2a: Supported \\
\hline Subjective Norm $\rightarrow$ WOM Intention & H2b: Supported \\
\hline Perceived Control $\rightarrow$ Intention to Use & H3a: Not supported \\
\hline Perceived Control $\rightarrow$ WOM Intention & H3b: Not supported \\
\hline Security $\rightarrow$ Intention to Use & H4a: Not supported \\
\hline Security $\rightarrow$ WOM Intention & H4b: Supported \\
\hline App Lifestyle Compatibility $\rightarrow$ Intention to Use & H5a: Supported \\
\hline App Lifestyle Compatibility $\rightarrow$ WOM Intention & H5b: Not supported \\
\hline Intention to Use $\rightarrow$ WOM Intention & H6: Supported \\
\hline
\end{tabular}

Note: ${ }^{a}$ the post hoc analysis revealed a significant moderating effect of age, that is, this relationship is significant for older customers. 


\subsection{Principal Findings}

Our results indicated that attitudes toward food delivery apps significantly predict consumers' behavioral intention to use and to spread WOM about the food delivery service. This conclusion is consistent with previous research, which also found that customer attitude is a predictor of behavioral intentions toward innovative services [28] and recommendations of services [125]. This finding suggests that consumers have a well-established attitude toward these apps and their implicit advantages (e.g., they remove the need to visit food shops or to cook at home); thus, the customer's favorable attitude plays an important role in the decision to use and recommend these services to other customers.

Our findings also showed that subjective norms related to food delivery apps significantly influenced customers' behaviors and WOM intentions. These findings suggest that consumers attach importance to the comments that those close to them make about food delivery apps. Thus, our results are consistent with previous studies, which concluded that the opinions held by family, friends, and colleagues influence individuals' decision-making in terms of use $[33,43]$ and in terms of recommending the service to others [48]. A consumer may think that people in his/her environment, who know him/her well, can help him/her make good choices.

Our initial results did not show that perceived control had a significant influence on the two loyalty intention variables. Given that mobile apps are continuously developing and younger consumers are more accustomed to interacting with these updates, we carried out a post hoc analysis to identify whether age might moderate the influence of perceived control on use and WOM intentions. Our results indicated that age moderates the effect of perceived control on WOM intention; that is, the effect of perceived control is significant for older customers. These findings revealed that younger consumers' decisions about food delivery apps are unaffected by perceptions that they control the apps, but that older customers (often having less confidence in their own ability to operate technologies) tend to value this characteristic when evaluating food delivery apps. In particular, perceived control is crucial for older customers in terms of making recommendations to others, suggesting that this customer segment needs to feel in control of an app before encouraging others to use it. These results are similar to those from previous studies, for example, in drone food delivery services, which have suggested that when older people have confidence in their use of a service they tend to recommend it to others more than do younger people [33].

The results of our study show that customer perceptions of security do not significantly influence intention to use, but do significantly influence WOM intentions. Therefore, our findings suggest that security concerns are important at a social level when deciding whether to recommend the service to others. This finding accords with previous studies, which have shown that a sense of responsibility drives prosocial behaviors such as making recommendations [82]. In other words, consumers are willing to take individual risks when using food delivery apps but will avoid exposing others to possible negative consequences.

Interestingly, our results showed that mobile app lifestyle compatibility has a significant influence on intention to use food delivery services, but not on intention to spread WOM about the service. These results suggest that consumers' lifestyles are important in the decision to use the apps at the personal, or private, level. Nevertheless, individuals may consider that, while they understand their own way of life, they may be unsure about others' lifestyles. Thus, consumers' lifestyles might affect the use of food delivery apps in a private context; however, consumers seem to understand that food delivery apps may not match others' lifestyles, and thus they prefer not to give possibly misleading information to other customers [49].

As proposed in the previous literature, intention to use positively affects WOM [57]. In the food delivery context, mobile apps offer consumers advantages, such as a wide variety of different food types, a user-friendly design, and real-time information about their order status. When consumers have positive experiences with apps they tend to inform other potential users about the app's benefits. Through this action, consumers feel good about their choices and the assistance they provide to the people in their close environment [94]. 
Finally, although the results of our study showed that gender does not affect intention to use and WOM intentions, we found that having an occupation exerted a significant effect on intention to use food delivery apps. In contrast to previous literature that does not often treat occupation as a potential variable in the explanation of behavior, our study revealed that employed people tend to use these applications more often than those who have no occupation. This finding is not surprising as, in comparison to other groups without occupations (e.g., unemployed, retired), workers tend to have more money and less time to cook or to go food shopping; thus, food delivery apps are a very convenient alternative for this customer segment.

\subsection{Theoretical Implications}

Focusing on the TPB model variables (i.e., attitude, the subjective norm, and perceived control), this study analyzes their impacts on the use and WOM intentions of food delivery mobile apps. Our research corroborated that attitude, a rational evaluation of choices based on the assessment of potential outcomes [35], is important in shaping use and WOM intentions in this context. The subjective norm, which is associated with normative beliefs and the individual's motivation to comply with these beliefs [35], is also an important motivational factor behind customers' behavioral intentions. In this vein, a customer may internalize others' recommendations and be motivated to pass them on to other customers. In this context, that food delivery apps are a modern, convenient service that might interest others. Indeed, this pattern replicates viral marketing processes, that is, individuals who receive valuable information share it with others in their networks [126].

Perceived control is related to the access that individuals have to the resources and abilities needed to perform certain behaviors, for example, technology, time, and skills. As previously mentioned, while being an important determinant in adoption of other technologies [30], the role of perceived control in the context of food delivery services is uncertain. Indeed, some previous studies on the use of mobile apps found that perceived control sometimes exerts a significant influence, and sometimes it does not (e.g., [31,32]). To address this issue, our research proposed that perceived control may be important sometimes, at least for some societal groups. A post hoc analysis revealed that the influence of perceived control is moderated by age, that is, perceived control is important for older customers of food delivery apps. Our research contributes by clarifying in which cases this theoretical relation is significant. Our findings suggested that age (as a moderating factor) might be included in the TPB framework when evaluating the influence of perceived control in similar contexts.

Focusing on the customers' perceptions about technology features, perceived security is associated with the app provider's actions to safeguard client information from security breaches during and after it is transmitted through the mobile phone [16]. Our research showed that customers recommend food delivery apps if they consider that they are secure. In this regard, our study contributes to the increasing body of evidence that suggests that customers are highly concerned about technology threats that may affect other members of the community.

From a more sociological approach our research contributes to the exploration of mobile app lifestyle compatibility as a precursor of loyalty felt toward food delivery apps. Previous studies noted that lifestyle is a key determinant in new technology adoption [36] and in the use of innovations [127], which suggests that people tend to adopt those technologies compatible with their values, norms, past experiences, and self-perception [128]. People normally use and recommend those things that fit their values, in very simple ways (e.g., replicating simple patterns that fit well with one's daily life). Our study confirms that customers' intentions to use food delivery apps are affected by their lifestyles, which suggests that this factor should not be ignored when analyzing customers' adoption of everyday technologies.

\subsection{Managerial Implications}

The results of our study show that customers' behavioral intentions toward food delivery services are influenced by their attitudes and subjective norms. Thus, companies should attach importance 
to the design of valuable user-friendly mobile apps; this will increase their customers' perceptions about the worth of these technology-based services. From their first interaction with the app customers should enjoy a positive and engaging experience. Furthermore, advertising campaigns should be carried out to persuade customers of the advantages of food delivery apps to increase their use and WOM intentions.

Given the importance of subjective norms as a social influence that determines individual customers' decisions regarding food delivery apps, special attention should be paid to increase the diffusion of information about these apps among peers. For instance, companies might implement rating schemes for food delivery apps to provide advice to those considering using or recommending them. To facilitate WOM among customers, companies might introduce social media platforms as part of their strategies [129]. In addition, professionals might follow win-win strategies to encourage consumers to spread WOM (e.g., those customers introducing another customer to the service could receive a discount on their next food order).

Food delivery companies and app developers should try to increase customers' perceived control when using apps, especially among older consumers. Companies should help this group to use their apps. To this end, training courses or video tutorials would be very useful customer-oriented actions. Other design-led strategies focused on this group of customers might use large clear letters and avoid showing disturbing ads during the operation of the app. In addition, the perception of higher control would motivate older customers to recommend the food delivery app to others, thus increasing the diffusion of the service among this target group.

Another way to increase WOM among customers of all ages would be to increase the information security of the food delivery app. Food delivery companies should provide customers with clear information about their security measures, not only as a basic feature but as a strategy to spread among customers and their networks. Managers need to understand that customers are concerned about security breaches. Investing in data protection and barriers against malware and providing privacy policy guidelines would help users improve their security perceptions. App developers should not only meet the minimum security standards established by industry regulations [16], but the highest security standards of the food delivery apps in the market.

Finally, our study concluded that both customers' lifestyles and having an occupation influence intention to use food delivery services. Consequently, companies should promote food delivery apps as services that match customers' lifestyles (e.g., eating at home, ordering by mobile phone) and as being particularly convenient for people who are busy in their work life. Advertising campaigns could take this into account when designing commercials (e.g., showing people using the food delivery app after a long working day). Promotions may also be adapted to these target groups. For instance, cross-selling tactics could be used to encourage users of other apps (e.g., mobile communication apps) to download food delivery apps; in addition, special discounts might be applied during office hours or when delivering to workplaces.

\subsection{Limitations and Further Research Lines}

The present study has some limitations that open interesting research avenues for future research. To generalize the results, the research could be replicated in other countries with different cultural orientations. Companies offering food delivery services may be different, depending on the country or even the city in which they operate; in some cases, some companies may have been established in a city for many years, whereas others may have just arrived, which may influence customer perceptions about their services. More detailed research into users' profiles and cultures might help professionals understand the specific personal and situational factors that might influence the use and WOM of their services.

A deeper study examining security concerns might help academics and practitioners to better understand consumers' worries about technologies and how to address them. In this respect it is important to distinguish between the different kinds of security issues that might arise in the use of 
these mobile apps. Complementarily, experimental studies could help academics and practitioners better understand how specific changes in app design and marketing campaigns might impact on the use and WOM of food delivery apps.

In addition, retailing is evolving at an extremely high speed [130]. As a result, new businesses such as smart lockers are entering the last-mile delivery sector [27]. In this ultra-competitive retail environment, understanding the new forms of value creation is crucial. Furthermore, due to global warming and environmental pollution concerns, companies are trying to provide eco-friendly products/services to meet customers' environmental demands of food delivery services [131]. Thus, future research must take account of the lifestyle compatibility of green food delivery services not only in regard to mobile apps, but also in relation to electric motorbikes and drones [132].

Author Contributions: Conceptualization, D.B., M.F. and A.P.-R.; methodology, software, and validation, D.B. and M.F.; formal analysis, investigation, resources, and data curation, D.B. and A.P.-R.; writing-original draft preparation, M.F.; writing-review and editing, D.B. and A.P.-R.; visualization, supervision, project administration, funding acquisition, D.B. All authors have read and agreed to the published version of the manuscript.

Funding: This research was supported by the European Social Fund and the Government of Aragon (group "METODO" S20_17R and LMP65_18).

Conflicts of Interest: The authors declare no conflict of interest.

\section{References}

1. De Kerviler, G.; Demoulin, N.T.; Zidda, P. Adoption of in-store mobile payment: Are perceived risk and convenience the only drivers? J. Retail. Consum. Serv. 2016, 31, 334-344. [CrossRef]

2. Martins, J.; Costa, C.; Oliveira, T.; Gonçalves, R.; Branco, F. How smartphone advertising influences consumers' purchase intention. J. Bus. Res. 2019, 94, 378-387. [CrossRef]

3. Cortiñas, M.; Chocarro, R.; Elorz, M. Omni-Channel users and omni-channel customers: A segmentation analysis using distribution services. Span. J. Mark.-ESIC 2019, 23, 415-436. [CrossRef]

4. Orús, C.; Gurrea, R.; Ibáñez-Sánchez, S. The impact of consumers' positive online recommendations on the omnichannel webrooming experience. Span. J. Mark.-ESIC 2019, 23, 397-414. [CrossRef]

5. Wang, X.; Yuen, K.F.; Wong, Y.D.; Teo, C.C. Consumer participation in last-mile logistics service: An investigation on cognitions and affects. Int. J. Phys. Distrib. Logist. Manag. 2019, 49, $217-238$. [CrossRef]

6. Chen, M.C.; Hsu, C.L.; Hsu, C.M.; Lee, Y.Y. Ensuring the quality of e-shopping specialty foods through efficient logistics service. Trends Food Sci. Technol. 2014, 35, 69-82. [CrossRef]

7. Visser, J.; Nemoto, T.; Browne, M. Home delivery and the impacts on urban freight transport: A review. Procedia-Soc. Behav. Sci. 2014, 125, 15-27. [CrossRef]

8. Mehmood, S.M.; Najmi, A. Understanding the impact of service convenience on customer satisfaction in home delivery: Evidence from pakistan. Int. J. Electron. Cust. Relatsh. Manag. 2017, 11, $23-43$.

9. Definición de Delivery. Available online: https://definicion.de/delivery/ (accessed on 20 April 2020).

10. Drahokoupil, J.; Piasna, A. Work in the Platform Economy: Deliveroo Riders in Belgium and the SMart Arrangement (15 January 2019). ETUI Research Paper-Working Paper, 2019. Available online: https: //papers.ssrn.com/sol3/papers.cfm?abstract_id=3316133 (accessed on 17 December 2019).

11. Alalwan, A.A. Mobile food ordering apps: An empirical study of the factors affecting customer e-satisfaction and continued intention to reuse. Int. J. Inf. Manag. Sci. 2020, 50, 28-44. [CrossRef]

12. Ehmke, J.F.; Mattfeld, D.C. Vehicle routing for attended home delivery in city logistics. Procedia-Soc. Behav. Sci. 2012, 39, 622-632. [CrossRef]

13. Bernal, E.; Mozas, A.; Medina, M.J.; Fernández, D. Evaluation of corporate websites and their influence on the performance of olive oil companies. Sustainability 2018, 10, 1274. [CrossRef]

14. Cho, M.; Bonn, M.A.; Li, J.J. Differences in Perceptions about food delivery apps between single-person and multi-person households. Int. J. Hosp. Manag. 2019, 77, 108-116. [CrossRef]

15. Statista: Online Food Delivery. Available online: https://www.statista.com/outlook/374/100/online-fooddelivery/worldwide (accessed on 20 April 2020). 
16. El País: El Auge De La Comida a Domicilio. Available online: https://elpais.com/economia/2017/12/01/ actualidad/1512125659_853869.html (accessed on 15 April 2020).

17. Balapour, A.; Nikkhah, H.R.; Sabherwal, R. Mobile application security: Role of perceived privacy as the predictor of security perceptions. Int. J. Inf. Manag. Sci. 2020, 52, 102063. [CrossRef]

18. Tong, S.; Luo, X.; Xu, B. Personalized mobile marketing strategies. J. Acad. Mark. Sci. 2020, 48, 64-78. [CrossRef]

19. Kim, M.J.; Lee, C.K.; Kim, J.S.; Petrick, J.F. Wellness pursuit and slow life seeking behaviors: Moderating role of festival attachment. Sustainability 2019, 11, 2020. [CrossRef]

20. Mobile App Download and Usage Statistics. Available online: https://buildfire.com/app-statistics/ (accessed on 13 April 2020).

21. Report: Smartphone Owners Are Using 9 Apps per Day, 30 per Month. Available online: https:// techcrunch.com/2017/05/04/report-smartphone-owners-are-using-9-apps-per-day-30-per-month/ (accessed on 20 April 2020).

22. What Do You Usually Pay per Order When Ordering Food Online? Available online: https://www.statista. com/statistics/705571/average-price-paid-per-food-order-in-the-us/ (accessed on 10 April 2020).

23. The Biggest Change in Fast Food Isn't about Food - and It Should Terrify Chains That Can't Keep Up. Available online: https://www.businessinsider.com/mobile-orderings-major-fast-food-impact-2016-4?IR=T (accessed on 19 April 2020).

24. Top 5 Food Delivery Apps in USA. Available online: www.icoderzsolutions.com/blog/top-5-food-deliveryapps-in-usa/ (accessed on 18 April 2020).

25. Acerca de Just Eat. Available online: https://www.just-eat.es/info/acerca-de-just-eat (accessed on 15 April 2020).

26. Kim, J.; Lee, K.H. Influences of motivations and lifestyles on intentions to use smartphone applications. Int. J. Advert. 2018, 37, 385-401. [CrossRef]

27. Yuen, K.F.; Wang, X.; Ma, F.; Wong, Y.D. The determinants of customers' intention to use smart lockers for last-mile deliveries. J. Retail. Consum. Serv. 2019, 49, 316-326. [CrossRef]

28. Belanche, D.; Cenjor, I.; Pérez-Rueda, A. Instagram stories versus Facebook wall: An advertising effectiveness analysis. Span. J. Mark.-ESIC 2019, 23, 69-94. [CrossRef]

29. Arpaci, I. Understanding and predicting students' intention to use mobile cloud storage services. Comput. Hum. Behav. 2016, 58, 150-157. [CrossRef]

30. Taylor, S.; Todd, P.A. Understanding information technology usage: A test of competing models. Inf. Syst. Res. 1995, 6, 144-176. [CrossRef]

31. Yang, K. Consumer technology traits in determining mobile shopping adoption: An application of the extended theory of planned behavior. J. Retail. Consum. Serv. 2012, 19, 484-491. [CrossRef]

32. Yang, H.C. Bon Appétit for apps: Young American consumers' acceptance of mobile applications. J. Comput. Syst. Sci. 2013, 53, 85-96. [CrossRef]

33. Hwang, J.; Kim, H. Consequences of a green image of drone food delivery services: The moderating role of gender and age. Bus. Strategy Environ. 2019, 28, 872-884. [CrossRef]

34. Kim, J.J.; Hwang, J. Merging the norm activation model and the theory of planned behavior in the context of drone food delivery services: Does the level of product knowledge really matter? J. Hosp. Tour. Manag. 2020, 42, 1-11. [CrossRef]

35. Ajzen, I. The theory of planned behavior. Organ. Behav. Hum. Decis. Process. 1991, 50, 179-211. [CrossRef]

36. Leung, L.; Chen, C. Extending the theory of planned behavior: A study of lifestyles, contextual factors, mobile viewing habits, TV content interest, and intention to adopt mobile TV. Telemat. Inform. 2017, 34, 1638-1649. [CrossRef]

37. Liao, C.; Chen, J.L.; Yen, D.C. Theory of planning behavior (TPB) and customer satisfaction in the continued use of e-service: An integrated model. Comput. Hum. Behav. 2007, 23, 2804-2822. [CrossRef]

38. Zhang, X.; Liu, S.; Wang, L.; Zhang, Y.; Wang, J. Mobile health service adoption in China. Online Inf. Rev. 2020, 44, 1-23. [CrossRef]

39. Hanafizadeh, P.; Keating, B.W.; Khedmatgozar, H.R. A systematic review of Internet banking adoption. Telemat. Inform. 2014, 31, 492-510. [CrossRef]

40. Belanche, D.; Casaló, L.; Flavián, C. Adopción de servicios públicos online: Un Análisis a través de la integración de los modelos TAM y TPB. Rev. Eur. Dir. Econ. Emp. 2011, 20, 41-56. 
41. Zhang, J.; Reithel, B.J.; Li, H. Impact of perceived technical protection on security behaviors. Inf. Manag. Comput. Secur. 2009, 17, 330-340. [CrossRef]

42. Kim, Y.; Peterson, R.A. A Meta-analysis of online trust relationships in e-commerce. J. Interact. Mark. 2017, 38, 44-54. [CrossRef]

43. Android Security Monthly Recap \#9: September 2019. Available online: https://lukasstefanko.com/2019/10/ android-security-monthly-recap-9.html (accessed on 11 April 2020).

44. Baabdullah, A.M.; Alalwan, A.A.; Rana, N.P.; Kizgin, H.; Patil, P. Consumer use of mobile banking (M-Banking) in Saudi Arabia: Towards an integrated model. Int. J. Inf. Manag. Sci. 2019, 44, 38-52. [CrossRef]

45. Casaló, L.V.; Flavián, C.; Guinalíu, M. The role of security, privacy, usability and reputation in the development of online banking. Online Inf. Rev. 2007, 31, 583-603. [CrossRef]

46. Wei, R. Lifestyles and new media: Adoption and use of wireless communication technologies in China. New Media Soc. 2006, 8, 991-1008. [CrossRef]

47. Mandel, N.; Rucker, D.D.; Levav, J.; Galinsky, A.D. The compensatory consumer behavior model: How self-discrepancies drive consumer behavior. J. Consum. Psychol. 2017, 27, 133-146. [CrossRef]

48. Shan, Y.; King, K.W. The effects of interpersonal tie strength and subjective norms on consumers' brand-related eWOM referral intentions. J. Interact. Advert. 2015, 15, 16-27. [CrossRef]

49. Eisingerich, A.B.; Chun, H.H.; Liu, Y.; Jia, H.M.; Bell, S.J. Why recommend a brand face-to-face but not on facebook? How word-of-mouth on online social sites differs from traditional word-of-mouth. J. Consum. Psychol. 2015, 25, 120-128. [CrossRef]

50. Bagozzi, R.P.; Dholakia, U.M. Antecedents and purchase consequences of customer participation in small group brand communities. Int. J. Res. Mark. 2006, 23, 45-61. [CrossRef]

51. Teo, T.; Lee, C.B. Explaining the intention to use technology among student teachers. Campus-Wide Inf. Syst. 2010, 27, 60-67. [CrossRef]

52. Hwang, J.; Kim, I.; Gulzar, M.A. Understanding the eco-friendly role of drone food delivery services: Deepening the theory of planned behavior. Sustainability 2020, 12, 1440. [CrossRef]

53. Ajzen, I.; Fishbein, M. Understanding Attitudes and Predicting Social Behavior; Pearson: London, UK, 1980.

54. Fishbein, M.; Ajzen, I. Belief, Attitude, Intention, and Behavior: An Introduction to Theory and Research; Addison-Wesley: Reading, MA, USA, 1977.

55. Chen, J.; Lobo, A. Organic food products in China: Determinants of consumers' purchase intentions. Int. Rev. Retail Distrib. Consum. Res. 2012, 22, 293-314. [CrossRef]

56. Crespo, Á.H.; del Bosque, I.R. The effect of innovativeness on the adoption of B2C e-commerce: A model based on the Theory of Planned Behaviour. Comput. Hum. Behav. 2008, 24, 2830-2847. [CrossRef]

57. Belanche, D.; Casaló, L.V.; Flavián, C. Providing online public services successfully: The role of confirmation of citizens' expectations. Int. Rev. Public Nonprofit Mark. 2010, 7, 167-184. [CrossRef]

58. Warshaw, P.R.; Davis, F.D. Disentangling behavioral intention and behavioral expectation. J. Exp. Soc. Psychol. 1985, 21, 213-228. [CrossRef]

59. Yi, Y.; Gong, T. The effects of customer justice perception and affect on customer citizenship behavior and customer dysfunctional behavior. Ind. Mark. Manag. 2008, 37, 767-783. [CrossRef]

60. Zeithaml, V.A.; Parasuraman, A.; Berry, L.L. Problems and strategies in services marketing. J. Mark. 1985, 49, 33-46. [CrossRef]

61. Hinz, O.; Skiera, B.; Barrot, C.; Becker, J.U. Seeding strategies for viral marketing: An empirical comparison. J. Mark. 2011, 75, 55-71. [CrossRef]

62. Harrison-Walker, L.J. The measurement of word-of-mouth communication and an investigation of service quality and customer commitment as potential antecedents. J. Serv. Res. 2001, 4, 60-75. [CrossRef]

63. Hwang, J.; Lee, J.S.; Kim, H. Perceived innovativeness of drone food delivery services and its impacts on attitude and behavioral intentions: The moderating role of gender and age. Int. J. Hosp. Manag. 2019, 81, 94-103. [CrossRef]

64. Flavián, C.; Gurrea, R. Users' motivations and attitude towards the online press. J. Consum. Mark. 2009, 26, 164-174. [CrossRef]

65. Belanche, D.; Casaló, L.V.; Flavián, C. The role of place identity in smart card adoption. Public Manag. Rev. 2014, 16, 1205-1228. [CrossRef] 
66. Wu, J.; Wang, S. What drives mobile commerce? An empirical evaluation of the revised technology acceptance model. Inf. Manag. 2005, 42, 719-729. [CrossRef]

67. Belanche, D.; Casaló, L.V.; Flavián, C. Artificial Intelligence in FinTech: Understanding robo-advisors adoption among customers. Ind. Manag. Data Syst. 2019, 119, 1411-1430. [CrossRef]

68. Fazio, R.H. Attitudes as object-evaluation associations: Determinants, consequences, and correlates of attitude accessibility. In Attitude Strength: Antecedents and Consequences Hillsdale; Petty, R.E., Krosnick, J.A., Eds.; Erlbaum: Hillsdale, NJ, USA, 1995; pp. 247-282.

69. Eagly, A.H.; Chaiken, S. The Psychology of Attitudes; Harcourt Brace Jovanovich: San Diego, CA, USA, 1993.

70. Research and Markets. Online Food Delivery Services Global Market Report 2020-30: COVID-19 Growth and Change. Available online: https://www.researchandmarkets.com/reports/5024095/online-food-deliveryservices-global-market (accessed on 22 May 2020).

71. Hwang, J.; Kim, H.; Kim, W. Investigating motivated consumer innovativeness in the context of drone food delivery services. J. Hosp. Tour. Manag. 2019, 38, 102-110. [CrossRef]

72. Venkatesh, V.; Davis, F. A theoretical extension of the technology acceptance model: Four longitudinal field studies. Manag. Sci. 2000, 46, 186-204. [CrossRef]

73. Harris, M.A.; Brookshire, R.; Chin, A.G. Identifying factors influencing consumers' intent to install mobile applications. Int. J. Inf. Manag. Sci. 2016, 36, 441-450. [CrossRef]

74. Kumar, A.; Adlakaha, A.; Mukherjee, K. The effect of perceived security and grievance redressal on continuance intention to use M-wallets in a developing country. Int. J. Bank Mark. 2018, 36, 1170-1189. [CrossRef]

75. DataProt: 30 Mobile App Statistics for the Informed Smartphone User. Available online: https://dataprot.net/ statistics/app-statistics/ (accessed on 14 April 2020).

76. Chin, A.G.; Harris, M.A.; Brookshire, R. A bidirectional perspective of trust and risk in determining factors that influence mobile app installation. Int. J. Inf. Manag. Sci. 2018, 39, 49-59. [CrossRef]

77. Johnson, V.L.; Kiser, A.; Washington, R.; Torres, R. Limitations to the rapid adoption of M-payment services: Understanding the impact of privacy risk on Mpayment services. Comput. Hum. Behav. 2018, 79, 111-122. [CrossRef]

78. Ooi, K.B.; Tan, G.W.H. Mobile technology acceptance model: An investigation using mobile users to explore smartphone credit card. Expert Syst. Appl. 2016, 59, 33-46. [CrossRef]

79. Susanto, A.; Chang, Y.; Ha, Y. Determinants of continuance intention to use the smartphone banking services. Ind. Manag. Data Syst. 2016, 116, 508-525. [CrossRef]

80. Hwang, J.; Choe, J.Y.J. Exploring perceived risk in building successful drone food delivery services. Int. J. Contemp. Hosp. Manag. 2019, 31, 3249-3269. [CrossRef]

81. Belanche, D.; Casaló, L.V.; Guinalíu, M. The Effect of Culture in Forming e-Loyalty Intentions: A Cross-cultural analysis between argentina and spain. Bus. Res. Q. 2015, 18, 275-292. [CrossRef]

82. Youn, S.; Kim, H. Antecedents of consumer attitudes toward cause-related marketing. J. Advert. Res. 2008, 48, 123-137. [CrossRef]

83. Zablocki, B.D.; Kanter, R.M. The differentiation of life-styles. Annu. Rev. Sociol. 1976, 2, 269-298. [CrossRef]

84. Cosmas, S.C. Life styles and consumption patterns. J. Consum. Res. 1982, 8, 453-455. [CrossRef]

85. Bourdieu, P. Distinction: A Social Critique of the Judgment of Taste; Routledge and Kegan Paul: London, UK, 1984.

86. Peter, P.J.; Olson, J.C. Understanding Consumer Behavior; Irwin: Burr Ridge, IL, USA, 1994.

87. Levy, S.J. Symbolism and Life Style. In Toward Scientific Marketing; Greyser, S.A., Ed.; American Marketing Association: Chicago, IL, USA, 1963; pp. 196-213.

88. McDonald, W.J. Time use in shopping: The role of personal characteristics. J. Retail. 1994, 70, 345-365. [CrossRef]

89. Shaw, N.; Sergueeva, K. The non-monetary benefits of mobile commerce: Extending UTAUT2 with perceived value. Int. J. Inf. Manag. 2019, 45, 44-55. [CrossRef]

90. Herrero, Á.; Pérez, A.; del Bosque, I.R. Values and Lifestyles in the Adoption of New Technologies Applying VALS Scale. Acad. Mark. Stud. J. 2014, 18, 29-47.

91. Karahanna, E.; Agarwal, R.; Angst, C.M. Reconceptualizing compatibility beliefs in technology acceptance research. MIS Q. 2006, 30, 781-804. [CrossRef] 
92. Lee, S.W.; Sung, H.J.; Jeon, H.M. Determinants of continuous intention on food delivery apps: Extending UTAUT2 with Information Quality. Sustainability 2019, 11, 3141. [CrossRef]

93. Hallowell, R. The relationships of customer satisfaction, customer loyalty and profitability: An empirical study. Int. J. Serv. Ind. Manag. 1996, 7, 27-42. [CrossRef]

94. Zhang, H.; Wang, Z.; Chen, S.; Guo, C. Product recommendation in online social networking communities: An empirical study of antecedents and a mediator. Inf. Manag. 2019, 56, 185-195. [CrossRef]

95. Brown, T.J.; Barry, T.E.; Dacin, P.A.; Gunst, R.F. Spreading the word: Investigating antecedents of consumers' positive word-of-mouth intentions and behaviors in a retailing context. J. Acad. Mark. Sci. 2005, 33, 123-138. [CrossRef]

96. Cheng, Y.S.; Yu, T.F.; Huang, C.F.; Yu, C.; Yu, C.C. The comparison of three major occupations for user acceptance of information technology: Applying the UTAUT model. IBusiness 2011, 3, 147. [CrossRef]

97. Alalwan, A.A.; Rana, N.P.; Dwivedi, Y.K.; Algharabat, R. Social media in marketing: A review and analysis of the existing literature. Telemat. Inform. 2017, 24, 1177-1190. [CrossRef]

98. Petrovčič, A.; Rogelj, A.; Dolničar, V. Smart but not adapted enough: Heuristic evaluation of smartphone launchers with an adapted interface and assistive technologies for older adults. Comput. Hum. Behav. 2018, 79, 123-136. [CrossRef]

99. Phillips, L.W.; Sternthal, B. Age differences in information processing: A perspective on the aged consumer. J. Mark. Res. 1977, 14, 444-457. [CrossRef]

100. Holbrook, M.B. Aims, concepts, and methods for the representation of individual differences in esthetic responses to design features. J. Consum. Res. 1986, 13, 337-347. [CrossRef]

101. Venkatesh, V.; Morris, M.G. Why don't men ever stop to ask for directions? Gender, social influence, and their role in technology acceptance and usage behavior. MIS Q. 2000, 24, 115-139. [CrossRef]

102. Cai, Z.; Fan, X.; Du, J. Gender and attitudes toward technology use: A meta-analysis. Comput. Educ. 2017, 105, 1-13. [CrossRef]

103. Reisdorf, B.C.; Groselj, D. Internet (non-) use types and motivational access: Implications for digital inequalities research. New Media Soc. 2017, 19, 1157-1176. [CrossRef]

104. Belanche, D.; Casaló, L.V.; Flavián, C.; Schepers, J. Trust transfer in the continued usage of public e-services. Inf. Manag. 2014, 51, 627-640. [CrossRef]

105. Cheung, M.F.; To, W.M. The influence of the propensity to trust on mobile users' attitudes toward in-app advertisements: An extension of the theory of planned behavior. Comput. Hum. Behav. 2017, 76, 102-111. [CrossRef]

106. Gracia, D.B.; Ariño, L.V.C.; Blanco, C.F. Understanding the influence of social information sources on e-government adoption. Inf. Res. 2012, 17, 1-21.

107. Kim, D.J.; Ferrin, D.L.; Rao, H.R. A trust-based consumer decision-making model in electronic commerce: The role of trust, perceived risk, and their antecedents. Decis. Support Syst. 2008, 44, 544-564. [CrossRef]

108. Dinsmore, J.B.; Swani, K.; Dugan, R.G. To "free" or not to "free": Trait predictors of mobile app purchasing tendencies. Psychol. Mark. 2017, 34, 227-244. [CrossRef]

109. Hair, J.J.F.; Hult, G.T.M.; Ringle, C.; Sarstedt, M. A Primer on Partial Least Squares Structural Equation Modeling (PLS-SEM), 2nd ed.; Sage Publications: Thousand Oaks, CA, USA, 2017.

110. Roldán, J.L.; Sánchez-Franco, M.J. Variance-based structural equation modeling: Guidelines for using partial least squares in information systems research. In Research Methodologies, Innovations, and Philosophies in Software Systems Engineering and Information Systems; Mora, M., Gel-Man, O., Steenkamp, A., Raisinghani, M.S., Eds.; Information Science Reference: Hershey, PA, USA, 2012; pp. 193-221.

111. Henseler, J.; Ringle, C.M.; Sinkovics, R. The use of partial least squares path modeling in international marketing. Adv. Int. Mark. 2009, 20, 277-319.

112. Fornell, C.; Larcker, D.F. Evaluating structural equation models with unobservable variables and measurement error. J. Mark. Res. 1981, 18, 39-50. [CrossRef]

113. Hu, L.T.; Bentler, P.M. Fit indices in covariance structure modeling: Sensitivity to underparameterized model misspecification. Psychol. Methods. 1998, 3, 424-453. [CrossRef]

114. Hair, J.F.; Ringle, C.M.; Sarstedt, M. PLS-SEM: Indeed a silver bullet. J. Mark. Theor. Pract. 2011, 19, $139-152$. [CrossRef]

115. Stone, M. Cross-validatory choice and assessment of statistical predictions. J. R. Stat. Soc. 1974, 36, 111-147. [CrossRef] 
116. Geisser, S. A predictive approach to the random effect model. Biometrika 1975, 61, 101-107. [CrossRef]

117. Tenenhaus, M.; Vinzi, V.E.; Chatelin, Y.M.; Lauro, C. PLS path modeling. Comput. Stat. Data Anal. 2005, 48, 159-205. [CrossRef]

118. Chung, M. The Effects of Product Feature Complexity, Market Activity, and Update Scheduling on Mobile App Life Cycles. Ph.D. Thesis, University of South Carolina, Columbia, SC, USA, 2019.

119. Venkatesh, V.; Morris, M.; Davis, G.; Davis, F. User Acceptance of Information Technology: Toward a Unified View. MIS Q. 2003, 27, 425-478. [CrossRef]

120. Liébana-Cabanillas, F.; Sánchez-Fernández, J.; Muñoz-Leiva, F. Antecedents of the adoption of the new mobile payment systems: The moderating effect of age. Comput. Hum. Behav. 2014, 35, 464-478. [CrossRef]

121. Morris, M.G.; Venkatesh, V. Age differences in technology adoption decisions: Implications for a changing work force. Pers. Psychol. 2000, 53, 375-403. [CrossRef]

122. Reed, K.; Doty, D.H.; May, D.R. The impact of aging on self-efficacy and computer skill acquisition. J. Manag. Issues 2005, 17, 212-228.

123. Trocchia, P.J.; Janda, S. A phenomenological investigation of internet usage among older individuals. J. Consum. Mark. 2000, 17, 605-616. [CrossRef]

124. Belanche, D.; Casaló, L.V.; Pérez-Rueda, A. Determinants of multi-service smartcard success for smart cities development: A study based on citizens' privacy and security perceptions. Gov. Inf. Q. 2015, 32, 154-163. [CrossRef]

125. Bagozzi, R.P.; Wong, N.; Abe, S.; Bergami, M. Cultural and Situational Contingencies and the Theory of Reasoned Action: Application to Fast Food Restaurant Consumption. J. Consum. Psychol. 2000, 9, 97-106. [CrossRef]

126. Wang, W.; Street, W.N. Modeling and maximizing influence diffusion in social networks for viral marketing. Appl. Netw. Sci. 2018, 3, 6. [CrossRef] [PubMed]

127. Zhu, K.; Dong, S.; Xu, S.X.; Kraemer, K.L. Innovation diffusion in global contexts: Determinants of post-adoption digital transformation of European companies. Eur. J. Inf. Syst. 2006, 15, 601-616. [CrossRef]

128. Rogers, E.M. Diffusion of Innovations; Simon and Schuster: New York, NY, USA, 2010.

129. Bernal-Jurado, E.; Mozas-Moral, A.; Fernández-Uclés, D.; Medina-Viruel, M.J. Explanatory factors for efficiency in the use of social networking sites-The case of organic food products. Psychol. Mark. 2017, 34, 1119-1126.

130. de Kervenoael, R.; Schwob, A.; Chandra, C. E-retailers and the engagement of delivery workers in urban last-mile delivery for sustainable logistics value creation: Leveraging legitimate concerns under time-based marketing promise. J. Retail. Consum. Serv. 2020, 54, 102016. [CrossRef]

131. Hwang, J.; Cho, S.B.; Kim, W. Consequences of psychological benefits of using eco-friendly services in the context of drone food delivery services. J. Travel Tour. Mark. 2019, 36, 835-846. [CrossRef]

132. Hwang, J.; Kim, W.; Kim, J.J. Application of the value-belief-norm model to environmentally friendly drone food delivery services: The moderating role of product involvement. Int. J. Contemp. Hospit. Manag. 2020. [CrossRef]

(C) 2020 by the authors. Licensee MDPI, Basel, Switzerland. This article is an open access article distributed under the terms and conditions of the Creative Commons Attribution (CC BY) license (http://creativecommons.org/licenses/by/4.0/). 